\title{
New genera of meliturguline bees from Saudi Arabia and Persia, with notes on related genera and a key to the Arabian fauna (Hymenoptera: Andrenidae)
}

\author{
Michael S. Engel ${ }^{1,2,3}$, Abdulaziz S. Alqarni ${ }^{4}$, Mohamed A. Shebl ${ }^{5}$, \\ Jennifer C. Thomas'
}

I Division of Entomology, Natural History Museum, 1501 Crestline Drive - Suite 140, University of Kansas, Lawrence, Kansas 66045-4415, USA 2 Department of Ecology \& Evolutionary Biology, University of Kansas, Lawrence, Kansas 66045, USA 3 Division of Invertebrate Zoology, American Museum of Natural History, Central Park West at 79 th Street, New York, New York 10024-5192, USA 4 Department of Plant Protection, College of Food and Agriculture Sciences, King Saud University, P.O. Box 2460, Riyadh 11451, Saudi Arabia 5 Department of Plant Protection, Faculty of Agriculture, Suez Canal University, Ismailia, Egypt

Corresponding author: Michael S. Engel (msengel@ku.edu)

Academic editor: Michael Ohl | Received 19 December 2018 | Accepted 20 February 2019 | Published 30 April 2019

http://zoobank.org/5B2D3ED0-DDC5-43A4-8564-AB18373F1F9B

Citation: Engel MS, Alqarni AS, Shebl MA, Thomas JC (2019) New genera of meliturguline bees from Saudi Arabia and Persia, with notes on related genera and a key to the Arabian fauna (Hymenoptera: Andrenidae). Journal of Hymenoptera Research 69: 1-21. https://doi.org/10.3897/jhr.69.32561

\begin{abstract}
A new genus of melitturgine bees (Panurginae: Melitturgini) is described and figured from central Saudi Arabia. Belliturgula najdica Engel, gen. et sp. n., is similar in several respects to the genus Flavomeliturgula Patiny in that both have a greatly elongate glossa that is longer than the face and is truncate apically. The former differs in the greatly elongate and flattened first labial palpomere, the remaining palpomeres unmodified, the greatly protuberant clypeus, and long labrum lacking dense setal patches, among other traits. In addition, remarks are made on the composition of Flavomeliturgula, with Meliturgula deserta Warncke (Iran, Pakistan), removed to Khuzimelissa Engel, gen. n., resulting in the new combination Khuzimelissa deserta (Warncke), comb. n. Khuzimelissa differs from Flavomeliturgula by the unmodified labial palpomeres (lacking the elongate first three labial palpomeres of the latter genus), the acute glossa (broadly truncate in the latter), glossa shorter than head length (greater than head length in the latter), the abundant, white, squamiform setae of the mesoscutum (sparse, erect setae in the latter), cleft pretarsal claws (simple in the latter), presence of metasomal setal bands (lacking in the latter), and apically emarginate pygidial plate
\end{abstract}

Copyright Michael S. Engel et al. This is an open access article distributed under the terms of the Creative Commons Attribution License (CC BY 4.0), which permits unrestricted use, distribution, and reproduction in any medium, provided the original author and source are credited. 
(acutely rounded in the latter). The species of Flavomeliturgula are organized into three subgenera, including Koreshomelissa Engel, subgen. n., and Freyamelissa Engel, subgen. n., and these may eventually warrant generic status once phylogenetic work on the tribe has been completed. A key to the Arabian genera of Panurginae is provided, along with an augmented key to the genera of subtribe Meliturgulina.

\section{Keywords}

Anthophila, Apoidea, Arabia, Melitturgini, Meliturgulina, Panurginae, taxonomy

\section{Introduction}

Bees of the panurgine tribe Melitturgini are uncommonly encountered in the Arabian fauna. Hitherto, the tribe has been represented in Arabia by only four species in two genera: Meliturgula scriptifrons (Walker) (=Poecilomelitta dzheddaensis Popov), M. ornata (Popov), Borgatomelissa brevipennis (Walker) (= Nomia eburneifrons Walker, M. arabica Popov), and B. niveopilosa Patiny (Walker 1871; Popov 1951; Patiny 2002). The biology of these bees in Arabia remains unstudied, and even basic records of floral associations are lacking. The latter two species have been considered related to Melitturga Latreille and segregated into a nominate subtribe, while the species of Meliturgula Friese are classified in the subtribe Meliturgulina. Three genera have been recognized in Meliturgulina: Gasparinabla Patiny, known only from a single, poorly preserved male from southwestern Iran; Flavomeliturgula Patiny, encompassing several species occurring across southern Iran and Pakistan; and Meliturgula, the largest genus of the group, with species distributed throughout Arabia and Africa but concentrated in southern Africa (Michener 2007).

Here we report a new species of meliturguline for the Arabian fauna, representing a new genus. Individuals of the species were found collecting pollen from Carthamus L. (Asteraceae: Carduoideae: Cynareae) in central Saudi Arabia (Figs 1, 2). The new species is somewhat similar to some species hitherto classified in Flavomeliturgula. We provide the description of the new taxon, along with notes on the systematics of Flavomeliturgula (e.g., Table 1). The new species as well as several of those hitherto classi-

Table I. Current classification of species discussed herein.

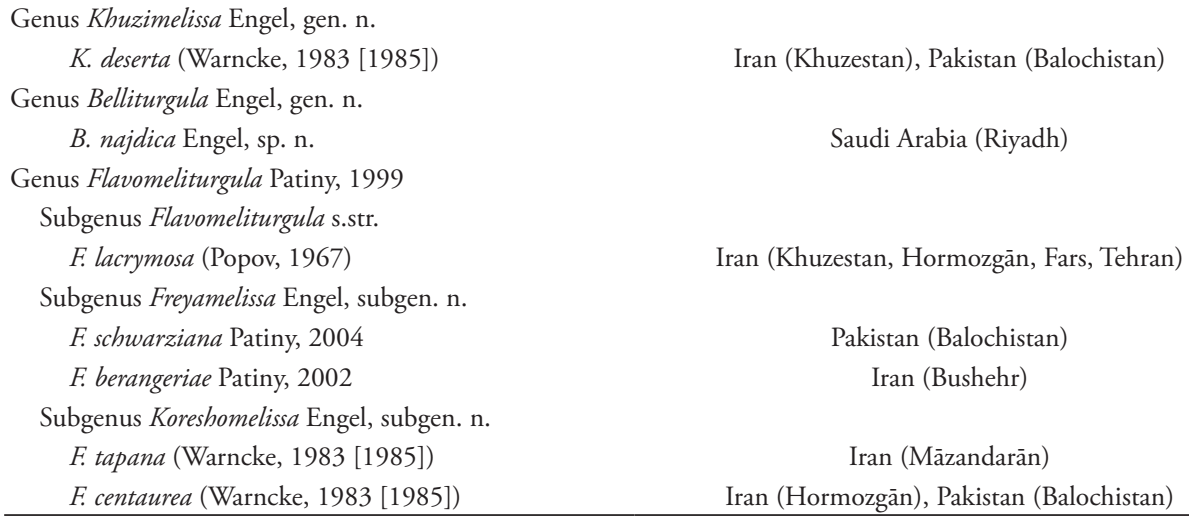



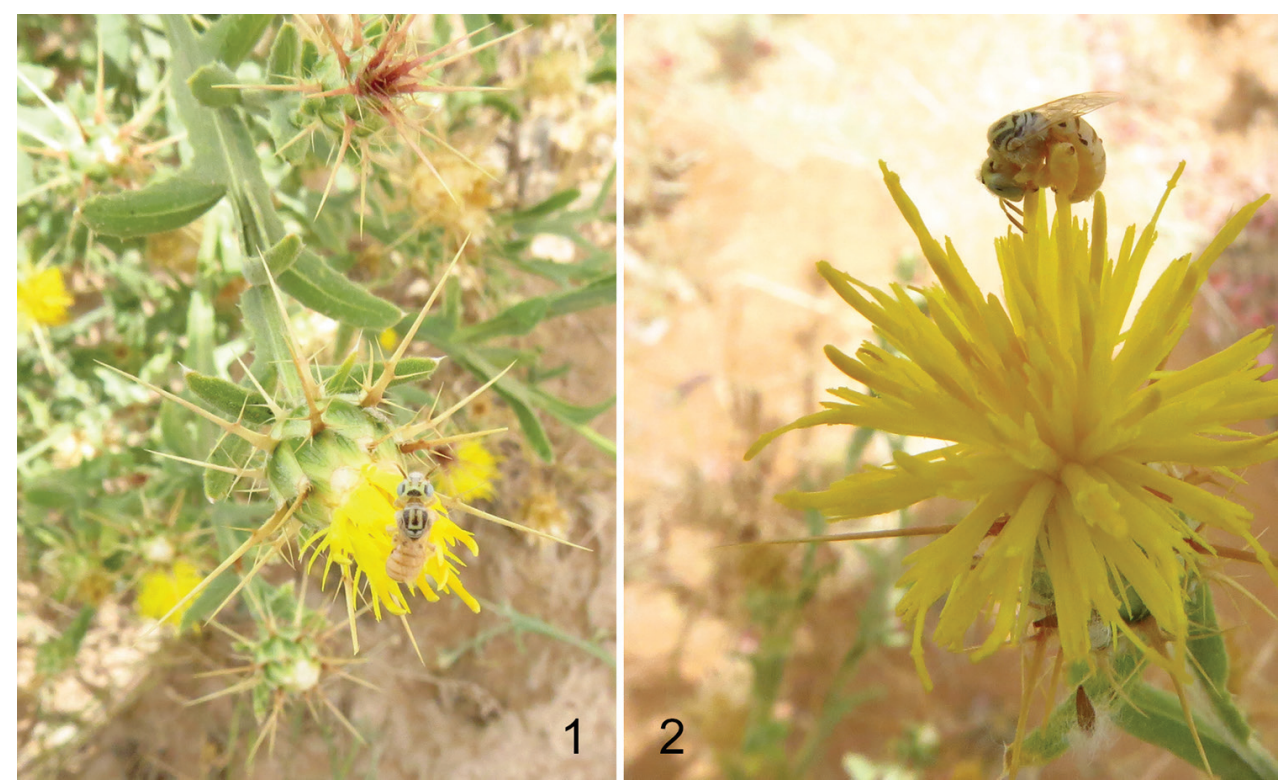

Figures I, 2. Female of Belliturgula najdica Engel, gen. et sp. n., at flowers of Carthamus L. (Asteraceae) in central Saudi Arabia.

fied in Flavomeliturgula are as different from one another as are traditionally differentiated as distinct genera among bees, particularly among different lineages of Panurginae (e.g., Ruz 1986, 1991; Patiny 2001; Roig-Alsina and Compagnucci 2003; Gonzalez and Engel 2011; Gonzalez et al. 2013, 2017; Ramos and Rozen 2014). Aside from differences in setation, coloration, and the shape of labra, sulci, pygidial plates, and other structural distinctions, the development of the mouthparts are strikingly different among these groups, and this may reflect some degree of difference in host plant visitation or specialization, much as is observed among other panurgine genera (e.g., Rozen and Ruz 1995; Rozen 2003). Accordingly, the classification is augmented in order to reflect and highlight these differences, and encourage melittologists to see out the biology of these rather different groups. In addition, we provide keys to the genera of Arabian Panurginae and to the genera of subtribe Meliturgulina.

\section{Material and methods}

The morphological terminology for the systematic work is largely taken from Engel (2001) and Michener (2007). Photographs were taken with a Canon 7D digital camera attached to an Infinity K-2 long-distance microscope lens, illuminated with a Xenon flash, while measurements were taken with an ocular micrometer on an Olympus SZX12 stereomicroscope. Specimens were examined from the collections of the Division of Entomology (Snow Entomological Collections), University of Kansas Natural 
History Museum, Lawrence, Kansas, USA (SEMC); the King Saud University Museum of Arthropods, Plant Protection Department, College of Food and Agriculture Sciences, King Saud University, Riyadh, Kingdom of Saudi Arabia (KSMA); and the Division of Invertebrate Zoology, American Museum of Natural History, New York, New York, USA; while types for the new species described herein are deposited in the former two institutions.

\section{Systematics}

Tribe Melitturgini Newman, 1834

Subtribe Meliturgulina Engel, 2001

\section{Belliturgula Engel, gen. n.}

http://zoobank.org/896747C8-0BD5-4B8B-8DBA-3C33E1CC588A

Type species. Belliturgula najdica Engel, sp. n.

Diagnosis. The genus resembles Flavomeliturgula in the elongate and apically truncate glossa but differs in the following attributes: body almost entirely pale yellow, with scattered dark brown to black markings; outer subantennal sulcus arched; clypeus greatly protuberant and extending well in front of compound eyes; labrum as long as wide, with distinct basilateral ovoid windows of translucent integument; proximal labial palpomere greatly elongate and flattened, twice as long as combined length of remaining palpomeres, extending well past apex of paraglossa; second through fourth labial palpomeres cylindrical, not flattened; apex of glossa not broadened; galea longer than stipes; mesoscutum covered with abundant, erect, minutely spicate, white setae; forewing $1 \mathrm{rs}-\mathrm{m}$ confluent with (rather than distad) $1 \mathrm{~m}$-cu; basal area of propodeum setose; probasitarsus short and broad, about twice as long as wide; mesotibial spur short, only about $0.5 \times$ length of mesobasitarsus; pygidial plate with margins concave apically and therefore more abruptly tapering to acutely rounded apex.

Description. Small species (less than $8 \mathrm{~mm}$ in total length); integument largely yellow, with some dark brown to black markings (Figs 1-5); head broader than long; compound eyes with inner margins parallel (Fig. 5); outer subantennal sulcus greatly arched outward (Fig. 5) (not straight); facial fovea shallow, narrower than median ocellar diameter, elongate, length approximately $5.5 \times$ width (Fig. 5 ); clypeus greatly protuberant, extending in front of compound eye by almost as much as compound eye width (Fig. 8) (protuberance extending in front of compound eye by distance approximately $0.85-0.95 \times$ compound eye width); labrum as long as wide, with basilateral ovoid areas ('windows') of translucent integument, without basilateral patches of dense, elongate, branched setae, with shallow, mediolongitudinal depression; ventral surface of prementum without abundant, long, posteriorly directed, simple setae (such setae present in Khuzimelissa); first labial palpomere greatly elongate and flattened, much longer than remainder of palpus (Fig. 12) (2x as long as combined lengths of remaining palpomer- 

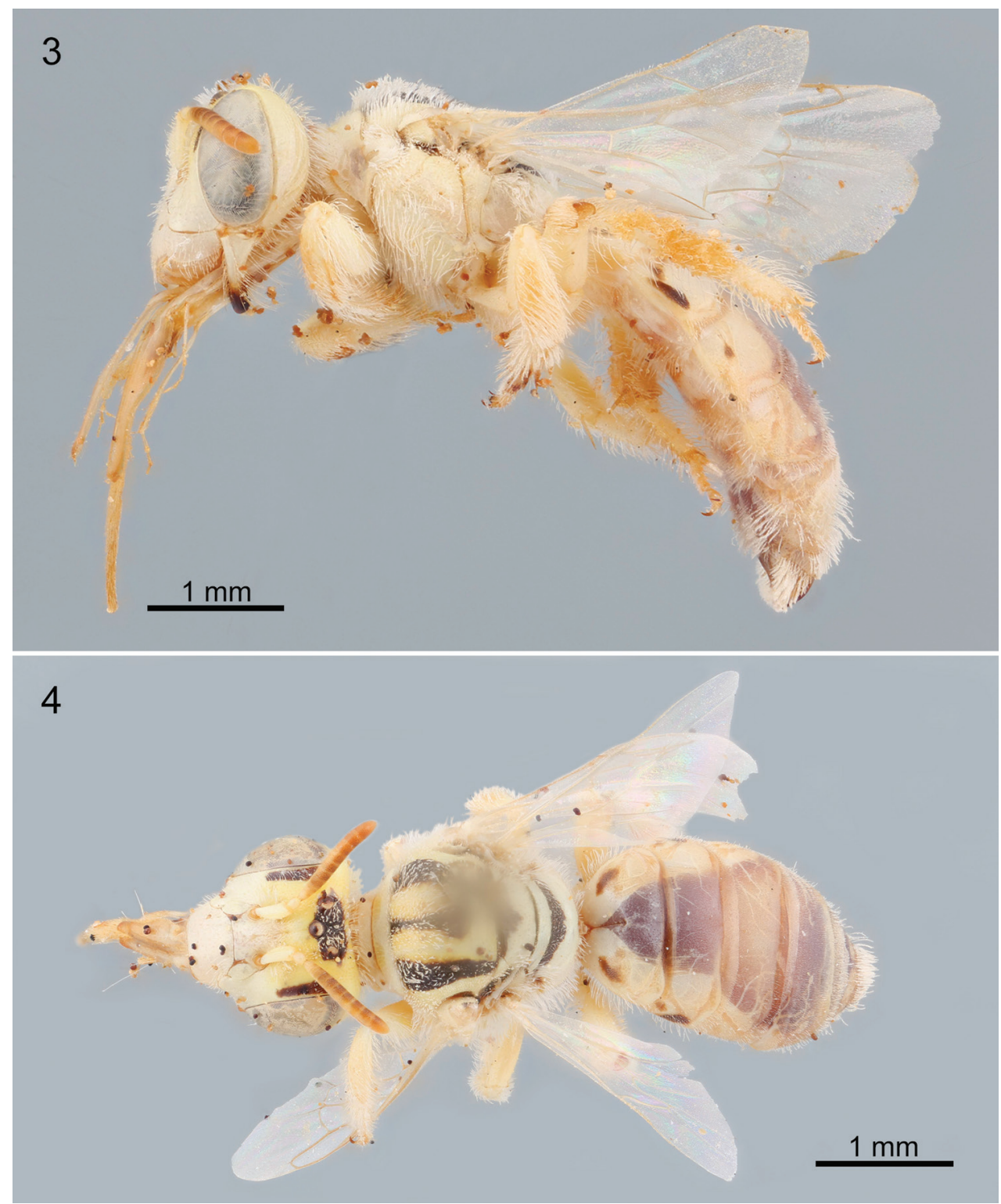

Figures 3, 4. Female of Belliturgula najdica Engel, gen. et sp. n., from central Saudi Arabia. 3 Lateral habitus 4 dorsal habitus.

es), extending greatly beyond apex of paraglossa, second palpomere not flattened, third through fourth palpomeres short, subequal in length, cylindrical (Fig. 12); glossa greatly elongate, distinctly longer than face (Fig. 8); apex truncate but not broadened (Fig. 9); galea longer than stipes (galea slightly longer than stipes in Flavomeliturgula; galea shorter than stipes in Khuzimelissa); mesoscutum with numerous scattered, erect, minutely spicate (pipecleaner-like in appearance), white setae, not obscuring integument (0.8-1.3x 


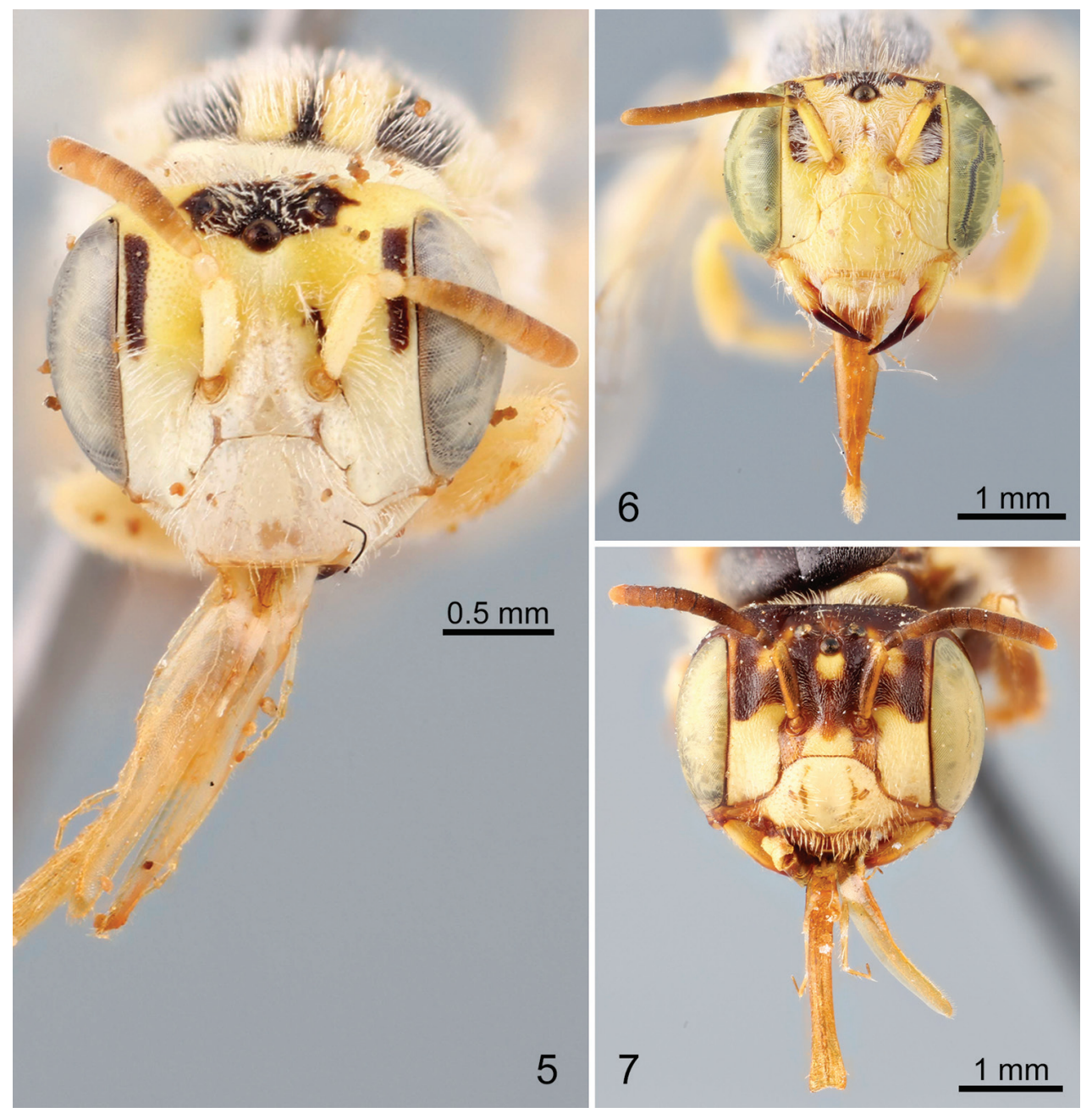

Figures 5-7. Female faces of representative Meliturgulina. 5 Belliturgula najdica Engel, gen. et sp. n., from Saudi Arabia (note arched outer subantennal sulci) 6 Khuzimelissa deserta (Warncke), comb. n., from Pakistan 7 Flavomeliturgula (Flavomeliturgula) lacrymosa (Popov) from Iran (note straight outer subantennal sulci).

median ocellar diameter) (Fig. 4); basal area of propodeum setose, setae not obscuring integument; forewing with pterostigma longer than wide, approximately $3.5 \times$ as long as wide, width subequal to length of prestigma, about $3.5 \times$ as long as prestigma, margin bordering first submarginal cell slightly diverging from anterior wing margin, border inside marginal cell converging toward anterior wing margin and with convex arch; marginal cell widely and slightly obliquely truncate at apex, longer than distance from its apex to wing tip; three submarginal cells present (i.e., 1rs-m present); length of first submarginal cell slightly greater than combined lengths of second and third submarginal cells; r-rs 
and 3Rs (anterior border of second submarginal cell) subequal; 2Rs and 1rs-m slightly converging anteriorly, thus second submarginal cell trapezoidal; 3Rs slightly longer than $0.5 \times 4 \mathrm{Rs}$ (anterior border of third submarginal cell); $1 \mathrm{rs}-\mathrm{m}$ confluent with $1 \mathrm{~m}$-cu (as in Gasparinhala); $1 \mathrm{cu}-\mathrm{a}$ at least $2 \times$ as long as $2 \mathrm{M}+\mathrm{Cu}$ (usually $2 \mathrm{M}+\mathrm{Cu}$ even shorter in other genera); hind wing with six distal hamuli; probasitarsus broad, about twice as long as wide (probasitarsus more elongate slender in Flavomeliturgula, nearly four times as long as wide); protibial calcar with velum rectangular, velum with outer and apical borders comparatively straight, malus (apical portion of rachis: sensu Engel et al., 2017) ciliate and slightly shorter than velum; mesofemur ventro-proximally forming nearly orthogonal angle (as in Flavomeliturgula, Meliturgula, Khuzimelissa, and related genera); mesotibial spur serrate, about $0.5 \times$ length of mesobasitarsus; metabasitibial plate broadly rounded, with carinate margins and surface covered in appressed, minute, plumose setae; metatibial and metabasitarsal scopa composed of abundant, elongate (1.8-3.2× median ocellar diameter), simple setae; pretarsal claws simple; metasomal terga without well-developed setal bands (Fig. 4) (present in Khuzimelissa); pygidial plate with apex narrowly rounded, margins tapering more prominently in apical half (Fig. 24).

Etymology. The generic name is an artificial combination of Bell, honoring explorer, archeologist, and nation-builder Gertrude Margaret Lowthian Bell (1868-1926), and a subset of Meliturgula Friese, type genus of the subtribe Meliturgulina. The name is therefore treated as a euphonious combination of letters and the gender of the name is considered to be feminine.

Included species. The genus includes at present only the type species, found in central Saudi Arabia.

\section{Belliturgula najdica Engel, sp. n.} http://zoobank.org/145B107D-91C2-424D-A736-5521CD3FF7DD Figs $1-5,8,9,12,24$

Diagnosis. As for the genus (vide supra).

Description. O : Total body length $7.08-7.33 \mathrm{~mm}$; forewing length $4.13-$ $4.27 \mathrm{~mm}$. Head broader than long, width $2.08-2.13 \mathrm{~mm}$, length $1.67-1.71 \mathrm{~mm}$; compound eyes with inner orbits margins roughly parallel, upper interorbital distance $1.33-1.38 \mathrm{~mm}$, lower interorbital distance $1.33-1.36 \mathrm{~mm}$; distance between compound eyes slightly greater than compound eye length; compound eye length $1.25 \mathrm{~mm}$, width $0.58-0.63 \mathrm{~mm}$; clypeus greatly protuberant, extending in front of compound eye by nearly compound eye width; intertegular distance $1.42-1.46 \mathrm{~mm}$.

Clypeus and supraclypeal area largely smooth with coarse, shallow (almost faint in most areas) punctures, such punctures separated by a puncture width or more, slightly denser along borders; labrum similar to clypeus except impunctate on transparent ovals; remainder of face similar except punctures smaller, more defined (albeit still shallow), and separated by a puncture width or frequently less; dark area between ocelli minutely and faintly imbricate and impunctate; facial fovea imbricate and impunctate; gena as on 


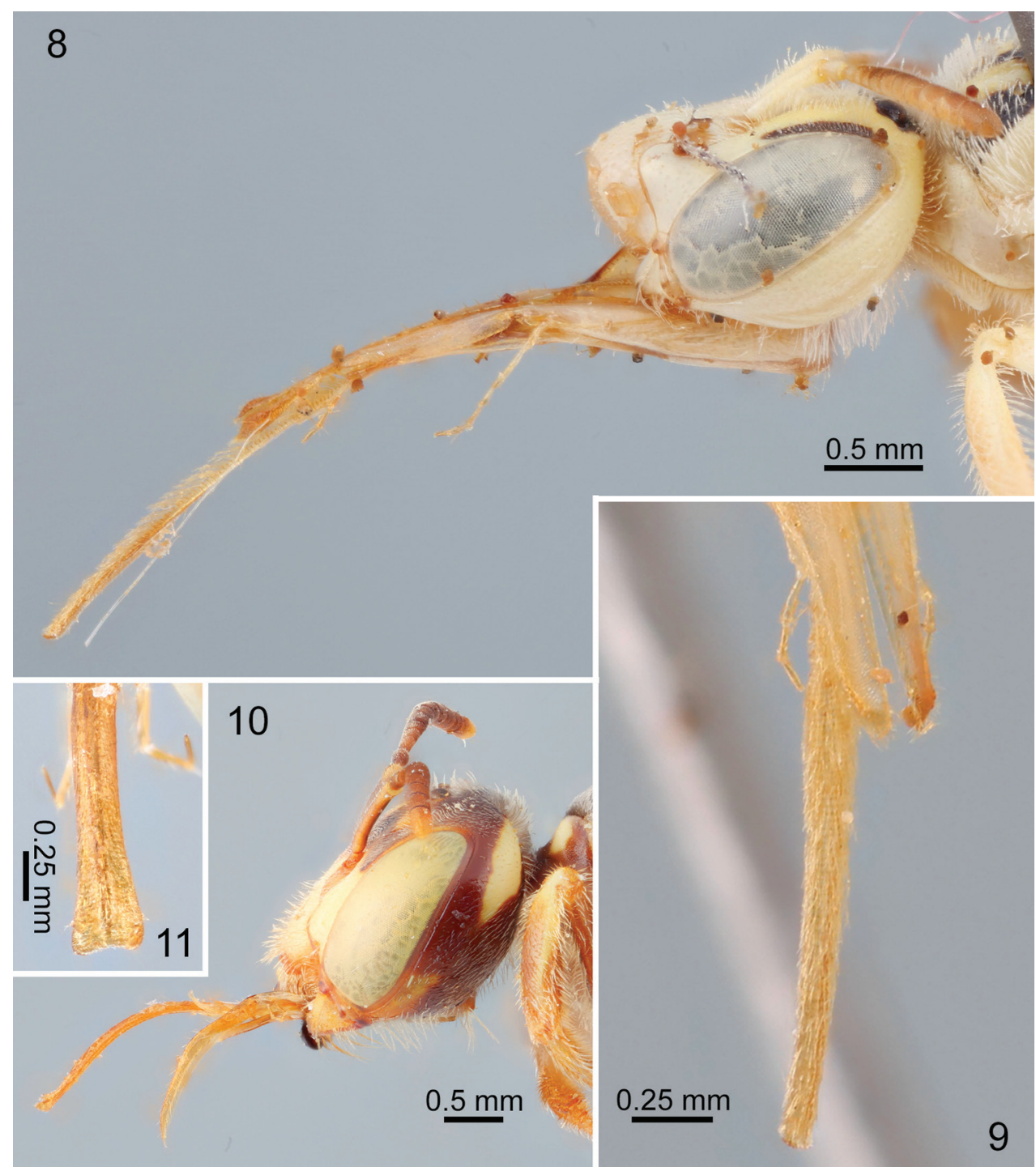

Figures 8-I I. Female heads and mouthparts in profile and details of glossal apexes. $8 \mathrm{Head}$ profile of Belliturgula najdica Engel, gen. et sp. n., from Saudi Arabia $\mathbf{9}$ glossal apex of B. najdica $\mathbf{1 0}$ head profile of Flavomeliturgula (Flavomeliturgula) lacrymosa (Popov) from Iran I I glossal apex of $F$. (F.) lacrymosa.

upper face except punctures becoming more sparsely separated ventrally; mesoscutum smooth to faintly and minutely imbricate with shallow punctures separated by a puncture width or less; mesoscutellum as on mesoscutum except punctures slightly denser and integument slightly more noticeably imbricate; metanotum as on mesoscutellum except shallow punctures nearly contiguous; pleura as on mesoscutum except punctures shallower and becoming sparse ventrally; basal area of propodeum as on metanotum; 
lateral and posterior surfaces of propodeum with small punctures separated by a puncture width or frequently less, integument between punctures smooth to faintly imbricate; metasomal terga minutely and finely imbricate with scattered shallow, faint, small punctures separated by a puncture width or less, such punctures most easily discernible on first tergum and becoming fainter on succeeding terga; pygidial plate minutely and finely imbricate; sterna as on terga except shallow, coarse punctures more prominent.

Integument generally pale yellow except marked with dark brown to black on mandibular apex, on facial fovea, around ocelli (Figs 4, 5); mesoscutum with three longitudinal dark stripes, medial stripe thin, terminating before posterior of mesoscutum, lateral stripes thicker, situated between lateral yellow borders and medial stripe, extending to axilla (Fig. 4); dark brown on lateral depression of axilla and along anterior border of mesoscutellum (slightly extended mediolongitudinally) (Fig. 4), and light brown anteriorly on basal area of propodeum (Fig. 4). Wing membranes clear, hyaline; veins pale yellow to off white (Fig. 3). Metasoma with light to dark brown marks as follows: paramedian spots on anterior-facing surface of first metasomal tergum (Fig. 4), elongate oval spots at lateral extremities of second tergum (Fig. 3), small spots on lateral extremities of third tergum (absent in some individuals); terga I-V with irregular brownish-purplish coloration (reflective of inner organs through pale integument) to varying degrees (in some individuals inner gut prominent through integument, others less so); pygidial plate brown, becoming reddish apically (Fig. 24); sterna pale brown, becoming darker on two apical sterna.

Pubescence generally white and largely sparse (Figs 3-5); facial setae generally short to moderate $(0.2-1.0 \times$ median ocellar diameter) in length and minutely spicate (i.e., minutely branched on all sides along entire length of rachis, with a pipecleaner-like appearance), such setae scattered on face and generally suberect; scape with similar moderate-length, erect, minutely spicate setae; minutely spicate setae longer $(0.9-1.5 \times$ median ocellar diameter) and erect around ocelli, vertex, posterior of gena, and postgena; mandible with more sparse, elongate (1.8-3.0× median ocellar diameter), simple setae along lower margin; mesoscutum with numerous erect short to moderate-length $(0.4-1.2 \times$ median ocellar diameter) minutely spicate setae, such setae not obscuring integument; mesoscutellum as on mesoscutum although setae slightly sparser; metanotum with minutely spicate setae sparse on disc, with various greatly elongate (up to $2.0 \times$ median ocellar diameter) minutely spicate setae at lateral extremities; pleura with numerous moderate-length to elongate (1.0-2.2× median ocellar diameter) minutely spicate setae, such setae not obscuring integument; basal area of propodeum with numerous fine minutely spicate setae, not obscuring integument; propodeum with lateral and posterior surfaces with pubescence similar to that of pleura; legs with minutely spicate setae except simple on tarsi and scopal setae of metatibia and metabasitarsus elongate (1.8-3.2× median ocellar diameter) and simple; metasoma with generally sparse pubescence, setae more numerous on apical terga where such setae minutely spicate and suberect to erect; setae particularly dense around pygidial plate and obscuring integument.

Oे: Latet. 

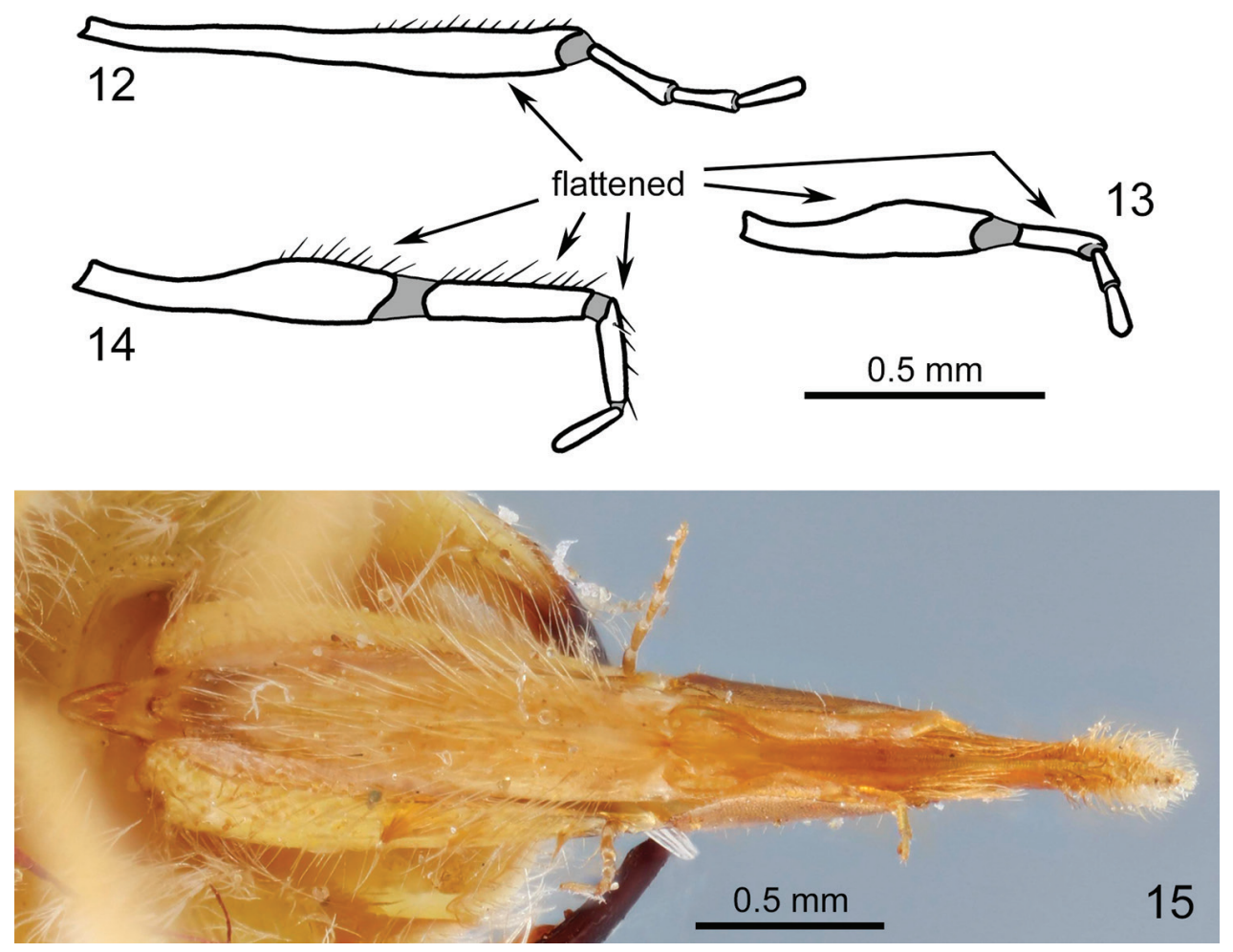

Figures 12-15. Labial palpi of representative species (to same scale) and labiomaxillary complex of Khuzimelissa deserta (Warncke), comb. n. (not to same scale), all in ventral view. 12 Labial palpus of Belliturgula najdica Engel, gen. et sp. n. 13 labial palpus of $K$. deserta 14 labial palpus of Flavomeliturgula (Flavomeliturgula) lacrymosa (Popov) I $\mathbf{5}$ photograph of labiomaxillary complex of $K$. deserta.

Holotype. + , KSA [Kingdom of Saudi Arabia], Riyadh [Region], Derab Agricul-

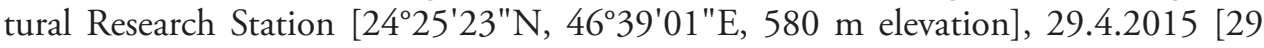
April 2015], M. Shebl, Carthamus [Asteraceae: Carthamus L.] (SEMC).

Paratypes. 2 9 , same data as holotype (SEMC, KSMA).

Etymology. The specific epithet is taken from the Najd, the vast geographic central plateau portion of Saudi Arabia which encompasses the type locality which is slightly south of the city of Riyadh.

Comments. The type series was collected from an unidentified species of distaff thistle (Asteraceae: Carduoideae: Carthamus L.) growing around the Dirab Agricultural Research Station in central Saudi Arabia (just south from Riyadh). The most common species of Carthamus in Saudi Arabia are Carthamus oxyacantha M.Bieb., which grows wild in many disturbed areas, and C. tinctorius Linnaeus (safflower), the latter widely cultivated, particularly so in southern Arabia (Mandaville, 1990). It is likely that the type series of B. najdica was captured at C. oxyacantha. Species of Carthamus are spiny, dentate herbs that can be largely self-pollinated, although among insects bees are the dominant pollinators (e.g., Butler et al., 1966). 
Khuzimelissa Engel, gen. n.

http://zoobank.org/FF287D5A-51DA-4BE4-A353-B1B896BB858D

Type species. Meliturgula deserta Warncke, 1983 [1985].

Diagnosis. The genus superficially resembles Flavomeliturgula and Belliturgula, particularly the latter in the extensive yellow coloration. However, the genus differs from both in the short, more typical labial palpomeres in which the proximal labial palpomere is elongate, flattened, longer than the combined lengths of the remaining palpomeres (approximately $1.25 \times$ length of remaining palpomeres combined), with the second palpomere flattened and slightly shorter than the length of the third and fourth palpomeres combined; and the third and fourth palpomeres subequal in length and cylindrical (Fig. 13). In addition, the glossa is acute (Figs 6, 15) (rather than broadly truncate apically), the glossa is shorter than the head length (Figs 6, 19-21) (rather than greater than the head length in the former two genera), the pretarsal claws are cleft (simple in the former two genera), the metasomal terga have distinctive broad setal bands (Figs 16-18) (lacking in the former two genera), and the pygidial

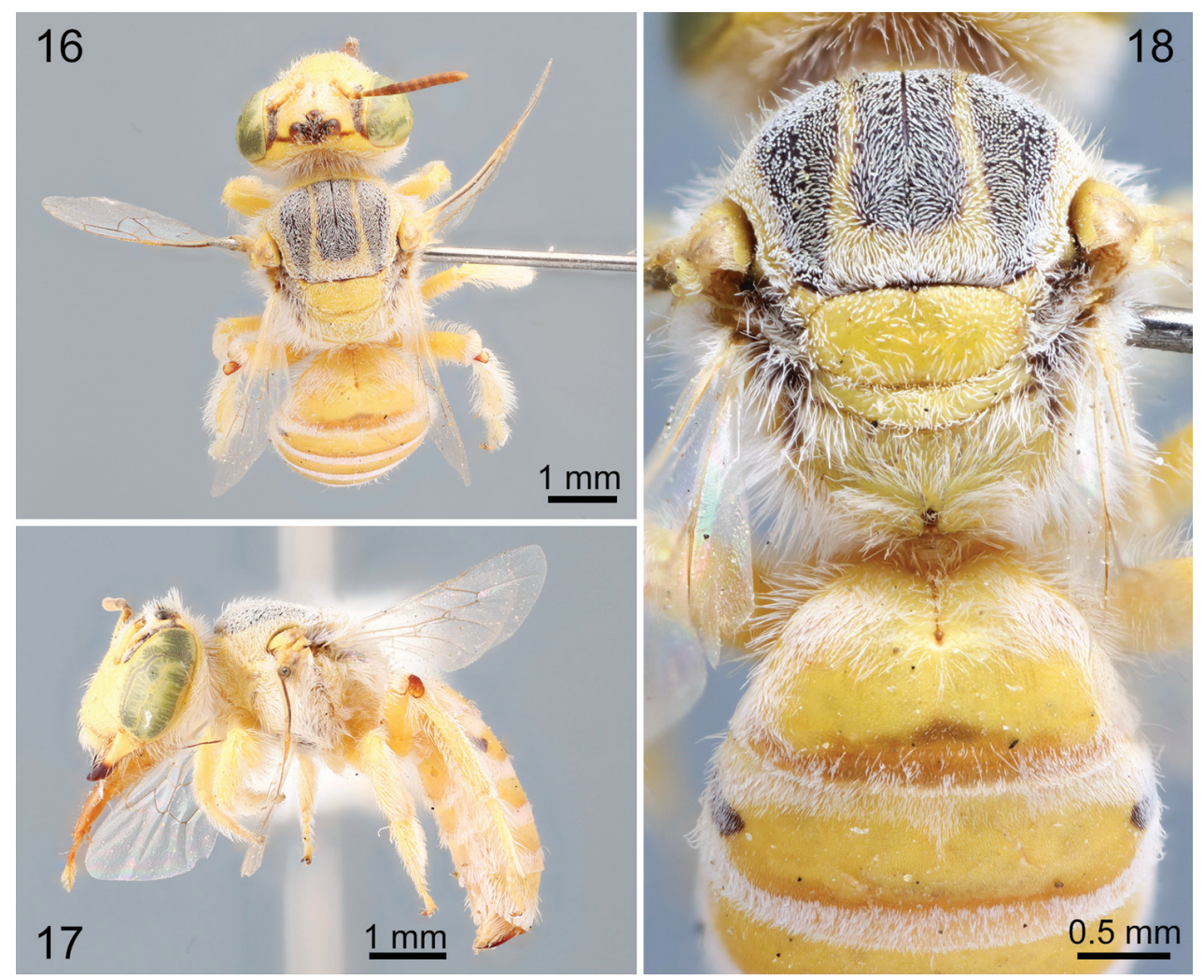

Figures 16-18. Female of Khuzimelissa deserta (Warncke), comb. n., from Pakistan. I6 Dorsal habitus 17 lateral habitus $\mathbf{I} 8$ detail of mesosoma and anterior metasomal dorsum. 


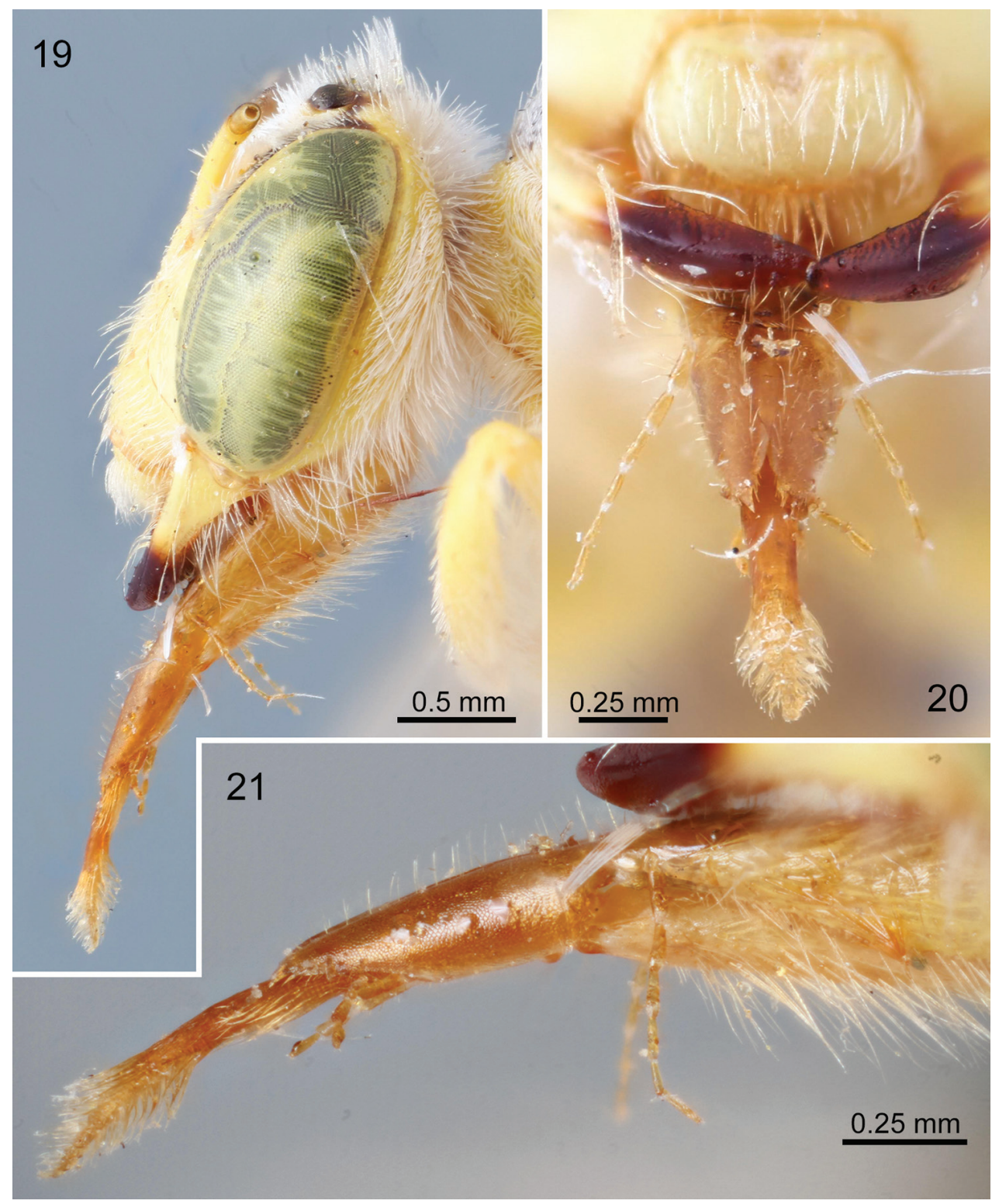

Figures 19-2I. Female of Khuzimelissa deserta (Warncke), comb. n., from Pakistan. I9 Head and mouthparts in profile $\mathbf{2 0}$ dorsal-frontal view of mouthparts $\mathbf{2} \mathbf{I}$ extended labiomaxillary complex in profile.

plate is apically emarginate (Fig. 25) (acutely rounded in the former two genera). Other diagnostic traits include: small species, slightly more than $8 \mathrm{~mm}$ in length; integument largely pale yellow with few dark brown to black markings (Figs 6, 16-18); outer subantennal sulcus arched (Fig. 6); clypeus gently and weakly convex, scarcely protuberant (Figs $6,17,19)$, extending in front of compound eye by about $0.5 \times$ com- 

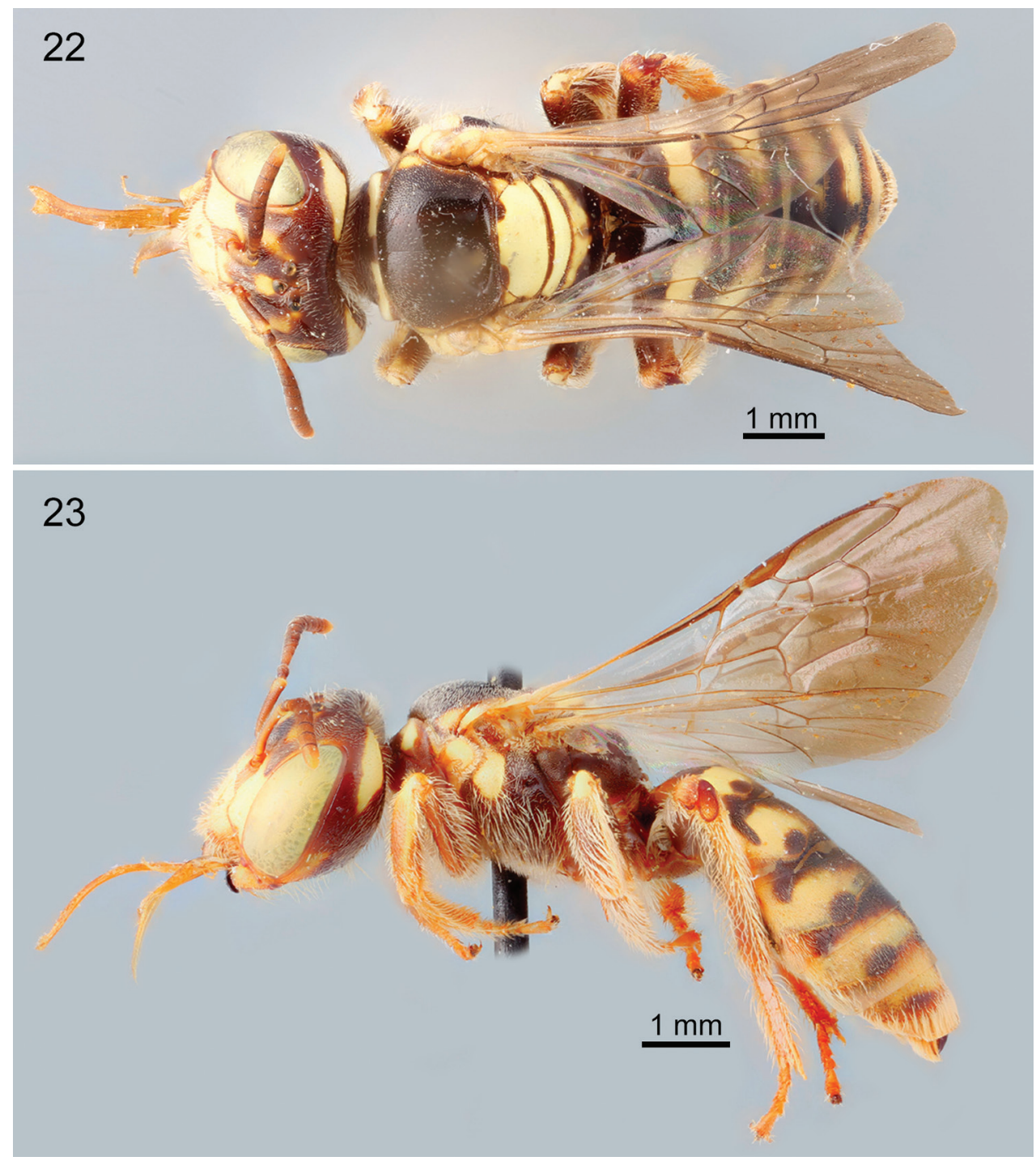

Figures 22, 23. Female of Flavomeliturgula (Flavomeliturgula) lacrymosa (Popov) from Iran. 22 Dorsal habitus 23 lateral habitus.

pound eye width; labrum wider than long, width $1.7 \times$ length, without lateral oval windows of transparent integument (Fig. 20), surface gently and weakly convex with weak subtriangular proximal medial depression; prementum ventrally with abundant, elongate (1.0-1.9× median ocellar diameter), erect to suberect, simple setae (Figs 15, 19, 21); galea shorter than stipes; mesoscutum with abundant, appressed, squamose setae (Fig. 18), intermixed with sparse, erect, minutely spicate setae $(0.8-1.0 \times$ median ocellar diameter); probasitarsus elongate, slender, length approximately $3 \times$ width; mesotibial spur about as long as mesobasitarsus; forewing with $\mathrm{r}$-rs distinctly shorter 


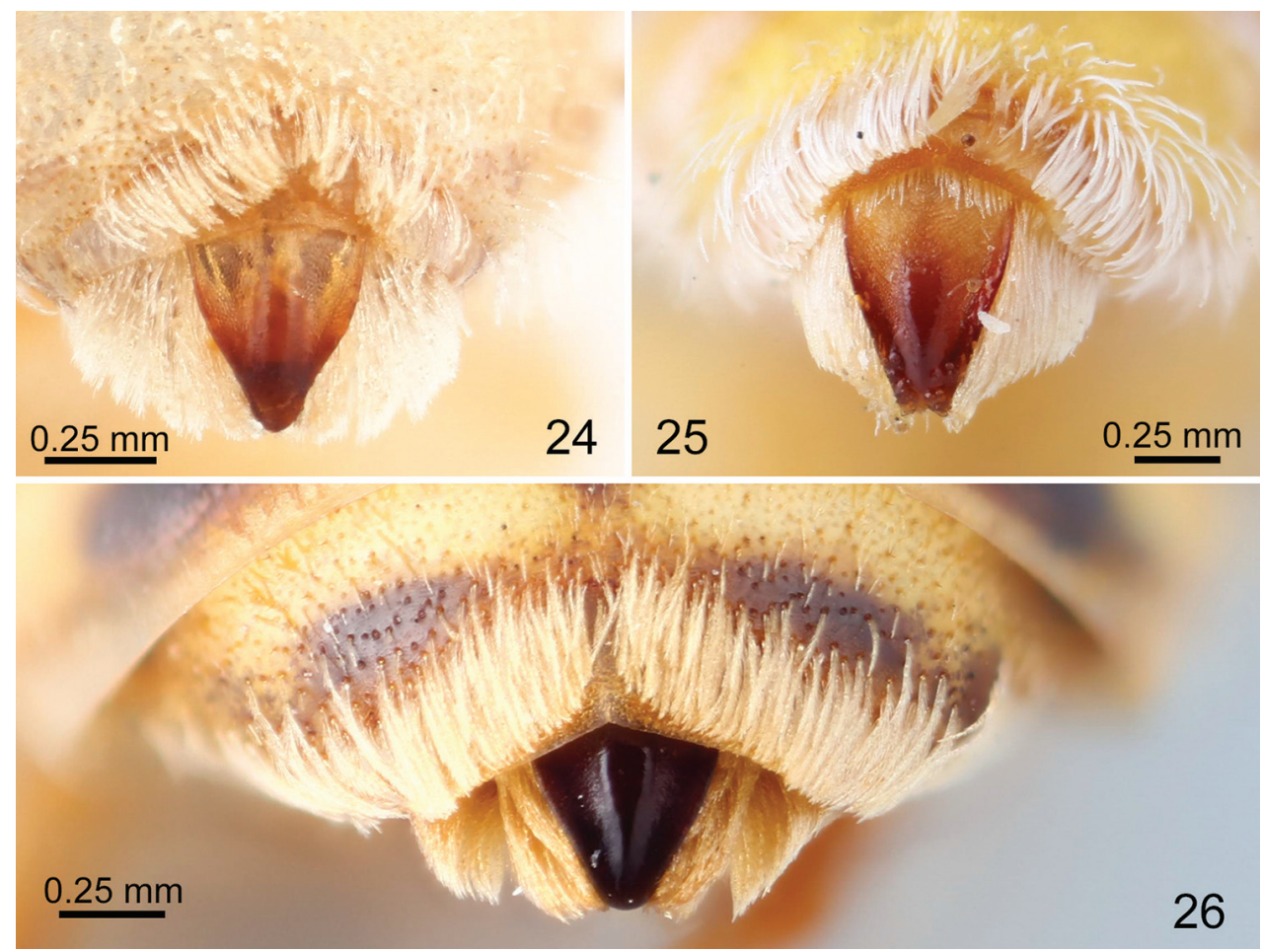

Figures 24-26. Female pygidial plates. 24 Belliturgula najdica Engel, gen. et sp. n. 25 Khuzimelissa deserta (Warncke), comb. n. 26 Flavomeliturgula (Flavomeliturgula) lacrymosa (Popov).

than $3 \mathrm{Rs}, 1 \mathrm{rs}-\mathrm{m}$ distad $1 \mathrm{~m}-\mathrm{cu}$, and $1 \mathrm{cu}-\mathrm{a}$ about $4 \times$ as long as $2 \mathrm{M}+\mathrm{Cu}$; hind wing with 10 or more distal hamuli arranged in a dense series.

Etymology. The new genus-group name is a combination of Khuzi, the Middle Persian name for the ancient Susian people, and from which the regional name Khuzestan derives (and encompasses the type locality of the type species), and the Greek,

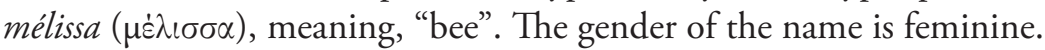

Included species. The genus presently includes only the type species, Khuzimelissa deserta (Warncke), comb. n., which has been recorded from Iran (Khuzestan) and Pakistan (Balochistan).

\section{Genus Flavomeliturgula Patiny}

Diagnosis. The genus can be generally differentiated from other members of the subtribe by the following combination of features: small to medium-sized bees, 5.0$10.0 \mathrm{~mm}$ in length; integument dark brown to brown with extensive yellow mark- 
ings (Figs 22, 23); outer subantennal sulcus straight (Fig. 7); clypeus weakly protuberant, extending in front of compound eye by about $0.35-0.5 \times$ compound eye width (Fig. 10); labrum wider than long, width $1.5 \times$ length, without lateral oval windows of transparent integument, surface with weakly raised, medial plateau, basilaterally with prominent setose patches composed of long (1.8-2.4× median ocellar diameter), subdecumbent setae; prementum ventrally without elongate setae; proximal labial palpomere elongate (but not extending past apex of paraglossa: in Belliturgula palpomere extends well past apex of paraglossa), flattened, about as long as to slightly longer than combined lengths of remaining palpomeres; second and third palpomeres flattened and elongate, together slightly shorter than to about as long as first palpomere, fourth palpomere short, shorter than preceding palpomere, cylindrical combined (Fig. 14); glossa greatly elongate, longer than head length, apex broadly truncate and broadened (Figs 7, 10,11); mesoscutum without appressed, squamose setae or abundant spicate setae (Fig. 22); forewing with 1rs-m distad $1 \mathrm{~m}$-cu (confluent in Belliturgula); probasitarsus elongate, slender, length approximately $4 \times$ width; mesotibial spur elongate, nearly $0.75 \times$ as long as mesobasitarsus; pretarsal claws simple; metasomal terga without distinctive broad setal bands; pygidial plate apically acutely rounded, with lateral margins tapering evenly toward apex, surface with mediolongitudinal ridge (Fig. 26).

\section{Key to Subgenera of Flavomeliturgula}

$1 \quad$ Propodeum basal area without setae; hind wing with 10 or more distal hamuli arranged in a dense series. Flavomeliturgula Patiny, s.str.

- $\quad$ Propodeum basal area with distinct setae; hind wing with 6-7 distal hamuli.

2(1) Mesoscutum brown to black with yellow markings; mesoscutum with minute, scattered setae, length of setae distinctly less than $0.5 \times$ median ocellar diameter Koreshomelissa Engel, subgen. n.

- $\quad$ Mesoscutum entirely black, without yellow markings; mesoscutum with scattered, white setae, particularly anteriorly, length of setae $1-1.5 \times$ median ocellar diameter. Freyamelissa Engel, subgen. n.

\section{Subgenus Flavomeliturgula Patiny}

Meliturgula (Flavomeliturgula) Warncke, 1983 [1985]: 229, nomen invalidum (no type species designated: ICZN 1999: Art. 13.3). Nota bene: Michener (2007) erroneously indicated the name as used by Warncke was a nomen nudum and included no species. In fact, Warncke did include four species and even provided scant diagnostic traits for the group (meaning it was not a nomen nudum), but only failed to explicitly designate a type species. 
Flavomeliturgula Patiny, 1999: 251. Type species: Poecilomelitta lacrymosa Popov, 1967, by original designation.

Diagnosis. The subgenus can be distinguished by the combination of: mesoscutum dark brown to black with yellow markings, surface with scattered, appressed, fine setae, such setae mostly anteriorly and laterally, and $0.5-0.75 \times$ median ocellar diameter; basal area of propodeum without setae; and hind wing with 10 or more distal hamuli arranged in a dense series along anterior wing margin.

Included species. The subgenus as here circumscribed is restricted to the type species, Flavomeliturgula lacrymosa (Popov), from Iran (Fars, Hormozgān, Khuzestan, Tehran).

\section{Koreshomelissa Engel, subgen. n.}

http://zoobank.org/9A888F48-0556-4243-A804-07000235BB63

Type species. Meliturgula tapana Warncke, 1983 [1985].

Diagnosis. The subgenus can be distinguished by the combination of: mesoscutum dark brown to black with yellow markings, surface with scattered, minute, fine setae, and less than $0.5 \times$ median ocellar diameter; basal area of propodeum with setae; and hind wing with 6-7 distal hamuli along anterior wing margin.

Etymology. The new subgeneric name is a combination of Kóréš or Küruš, the Hebrew and Persian names for Cyrus the Great (Cyrus II, ca. 600-530 B.C.), who first unified the ancient kingdoms of the Near East and founded the Achaemenid Empire of Persia, combined with the Greek, mélissa ( $\mu \dot{e} \lambda \iota \sigma \sigma \alpha)$, meaning, "bee". The gender of the name is feminine.

Included species. The subgenus includes two species: F. (Koreshomelissa) tapana and $F$. $(K$.$) centaurea (Warncke), both from northern (along the Caspian Sea) and southern$ costal Iran (Māzandarān and Hormozgān) and southern Pakistan (Balochistan).

\section{Freyamelissa Engel, subgen. n.}

http://zoobank.org/6F683DEC-CFBB-4FFA-B998-9D4333967A4B

Type species. Flavomeliturgula berangeriae Patiny, 2002.

Diagnosis. The subgenus can be distinguished by the combination of: mesoscutum entirely black without yellow maculation, surface with scattered setae of 1-1.5x median ocellar diameter; basal area of propodeum with setae; and hind wing with 6-7 distal hamuli along anterior wing margin.

Etymology. The new subgeneric name is a combination of Freya, for the famed explorer of Arabia, Persia, and Afghanistan, Freya Madeline Stark (1893-1993), and the Greek, mélissa ( $\mu \dot{\varepsilon} \lambda \iota \sigma \sigma \alpha)$, meaning, "bee". The gender of the name is feminine.

Included species. The subgenus includes two species: F. (Freyamelissa) berangeriae and $F(F)$ schwarziana Patiny, from southwestern Iran (Bushehr) and southern Pakistan (Balochistan). 


\section{Key to Genera of Saudi Arabian Panurginae}

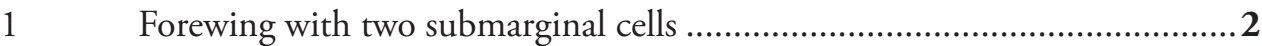

- Forewing with three submarginal cells .................................................... 3

2(1) S6 of male with posterior margin thin and more or less straight or usually broadly bilobed but usually without an apical zone of very short setae; episternal groove present but usually short, not reaching level of scrobe, or rarely absent; $1 \mathrm{~m}$-cu distal to $1 \mathrm{rs}-\mathrm{m}$, joining second submarginal cell

Panurgus Panzer

- $\quad$ S6 of male with posterior margin slightly to strongly produced medially, this projection with truncate to broadly concave apex margined by zone of short setae; episternal groove entirely absent (body entirely black except for yellow clypeus of some males; $1 \mathrm{~m}$-cu meeting or basal to $1 \mathrm{rs}-\mathrm{m}$ or nearly so

Panurginus Nylander

3(1) First labial palpomere greatly elongate and flattened, much longer than remainder of palpus, third through fourth palpomeres short, subequal in length, cylindrical; glossa longer than face, with apex truncate; body wholly yellow with few black markings on head and mesosomal dorsum

Belliturgula Engel, gen. n.

- $\quad$ First labial palpomere elongate, as long as or longer than second to fourth palpomeres together; glossa pointed; body variable mostly dark, never wholly

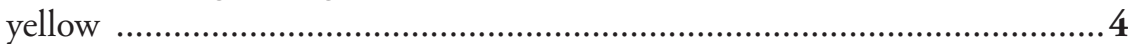

4(3) Mesoscutum of female densely covered with short, thickened, appressed setae among which are scattered erect setae; male gonostylus very slender, as long as gonocoxite; volsella spiculate, extending beyond gonocoxites; seventh metasomal tergum of male with bifid apex; sixth and seventh metasomal sterna of male with deep medioapical emarginations.....

Borgatomelissa Patiny Mesoscutum of female with scattered suberect setae or in some species with appressed setae, less dense than as above; male gonostylus robust, half as long as gonocoxite or less; volsella not spiculate, extending little if at all beyond gonocoxites; seventh metasomal tergum of male with apex simple; sixth and seventh metasomal sterna of male with apical margins transverse or convex..

Meliturgula Friese

\section{Key to Genera of Meliturgulina}

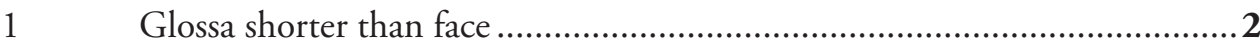

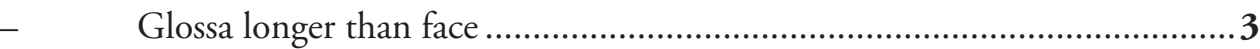

2(1) Body largely yellow; pygidial plate of female emarginate apically, surface with weak mediolongitudinal ridge, faintly imbricate

Khuzimelissa Engel, gen. n.

- $\quad$ Body largely black with areas of yellow maculation; pygidial plate of female rounded apically, surface flat, imbricate Meliturgula Friese 
3(1) Glossal apex broadly truncate; maxillary palpus with six palpomeres........... 4

- Glossal apex acute; maxillary palpus apparently vestigial ("nearly absent" according to Patiny, 2001)

Gasparinabla Patiny

4(3) Proximal labial palpomere greatly elongate, more than $2 \times$ as long as combined lengths of remaining palpomeres, extending greatly beyond apex of paraglossa; remaining palpomeres not flattened; outer subantennal sulcus of female greatly arched; female clypeus greatly protuberant, in profile extending in front of compound eye by about compound eye width; female labrum as long as wide, without medioapical elevated plateau and without basilateral patches of dense, long, branched setae

Belliturgula Engel, gen. n.

- $\quad$ Proximal three labial palpomeres long, flattened; first labial palpomere not extending past apex of paraglossa, shorter than combined lengths of remaining palpomeres; outer subantennal sulcus straight; clypeus weakly protuberant, in profile extending in front of compound eye by much less than compound eye width; female labrum wider than long, with medioapical elevated circular or ovoid plateau, with basilateral patches of dense, long, branched setae........

Flavomeliturgula Patiny

\section{Discussion}

The diversity of bee genera occurring across the Arabian Peninsula has been summarized most recently by Dathe (2010) and Engel et al. (2013, 2017). In recent years several genera have been added to the Arabian fauna, including Melitta Kirby (Melittidae), Compsomelissa Alfken, and Tarsalia Morawitz (both Apidae) (Alqarni et al., 2014; Shebl et al., 2016; Engel et al., 2014, 2017). Prior to the present work, 45 genera of bees have been documented from Saudi Arabia (Engel et al., 2017), and only four panurgines (Borgatomelissa, Meliturgula, Panurginus Nylander, and Panurgus Panzer). None of these previously documented genera are endemic to Arabia (e.g., Patiny and Michez 2007; Michener 2007), and most of these genera are widely distributed across the Palaearctic or even throughout the Old World. Here we record a unique member of the panurgine tribe Melitturgini, representing a genus allied to a group of species largely occurring across Persia and encompassing a variety of morphologies, as documented above. The few known occurrences for the groups discussed herein (Table 1) are loosely analogous to those of species in the genus Tarsalia (Apinae: Tarsaliini) (Engel et al., 2017). The subgenera and species of Tarsalia are distributed across Persia and the Middle East, but also extend into western India and into Central Asia to the East and into Egypt and Sudan in the West. Unfortunately, the biology of this group of bees, comprising the genera Belliturgula, Flavomeliturgula, and Khuzimelissa, remains largely unknown aside from a few floral records. Interestingly, like the new Arabian species described herein, other species where records are available from Iran have also been found at flowers of the thistle subfamily Carduoideae (Asteraceae), and specifically visiting the genera Centaurea L. and Carthamus L. (both of tribe Cynareae) (Warncke, 1983). It is possible that all of these 
genera are oligolectic on genera of Carduoideae or more generally across Asteraceae. It is greatly hoped that by drawing attention to these unique bees, and the interesting mouthpart specializations found in each (e.g., glossal structure, forms of the labial palpi, premental setation), that efforts will be made to seek out further material in the field, obtain observations on their floral visitation behaviors, locate nests and immatures, and discover the unknown males or females since many of these species are known from a single sex. It is likely such exploration will also uncovered as of yet unknown species, as well as document additional localities from which meaningful distributions can be mapped, ecological niches determined, and broader biogeographic patterns revealed. Naturally, a comprehensive phylogeny of meliturgulines would be of considerable value, but at present the rarity of material (i.e., only one species of the group is known from both sexes and from any substantial number of locality records and specimens) hinders any meaningful study as characters would ideally be drawn from both males and females. Similarly, for DNA sequence data additional collections from the field are necessary. Ultimately, more fieldwork is necessary across the regions in which these bees occur.

\section{Acknowledgements}

The authors extend their appreciation to the International Scientific Partnership Program (ISPP) at King Saud University for funding this research through ISPP \#0083. The manuscript received important and helpful reviews from two anonymous evaluators, to whom we are most grateful.

\section{References}

Alqarni AS, Hannan MA, Engel MS (2014) First record of the bee genus Compsomelissa in the Kingdom of Saudi Arabia (Hymenoptera: Apidae). Pan-Pacific Entomologist 90(1): 37-39. https://doi.org/10.3956/2014-90.1.37

Butler Jr GD, Werner FG, Levin MD (1966) Native bees associated with safflower in south central Arizona. Journal of the Kansas Entomological Society 39(3): 434-436.

Dathe HH (2009) Order Hymenoptera, superfamily Apoidea: Families Colletidae, Andrenidae, Halictidae, Melittidae, Megachilidae and Apidae. Arthropod Fauna of the UAE 2: $335-432$.

Engel MS (2001) A monograph of the Baltic amber bees and evolution of the Apoidea (Hymenoptera). Bulletin of the American Museum of Natural History 259: 1-192. https://doi. org/10.1206/0003-0090(2001)259<0001:AMOTBA>2.0.CO;2

Engel MS, Alqarni AS, Hannan MA (2013) A preliminary list of bee genera in the Kingdom of Saudi Arabia (Hymenoptera: Apoidea). Journal of the Saudi Society of Agricultural Sciences 12(1): 85-89. https://doi.org/10.1016/j.jssas.2012.08.001

Engel MS, Alqarni AS, Hannan MA, Hinojosa-Díaz IA, Michener CD (2014) Allodapine bees in the Arabian Peninsula (Hymenoptera: Apidae): a new species of Braunsapis from the 
Sarawat Mountains, with an overview of the Arabian fauna. American Museum Novitates 3801: 1-15. https://doi.org/10.1206/3801.1

Engel MS, Alqarni AS, Shebl MA (2017) Discovery of the bee tribe Tarsaliini in Arabia (Hymenoptera: Apidae), with the description of a new species. American Museum Novitates 3877: 1-28. https://doi.org/10.1206/3877.1

Gonzalez VH, Engel MS (2011) Andinopanurgus, a new Andean subgenus of Protandrena (Hymenoptera, Andrenidae). ZooKeys 126: 57-76. https://doi.org/10.3897/zookeys.126.1676

Gonzalez VH, Rasmussen C, Engel MS (2013) Incasarus garciai, a new genus and species of panurgine bees from the Peruvian Andes (Hymenoptera: Andrenidae). Journal of Melittology 8: 1-9. https://doi.org/10.17161/jom.v0i8.4506

Gonzalez VH, Smith-Pardo AH, Engel MS (2017) Phylogenetic relationships of a new genus of calliopsine bees from Peru, with a review of Spinoliella Ashmead (Hymenoptera: Andrenidae). Bulletin of the American Museum of Natural History 412: 1-71. https://doi. org/10.1206/0003-0090-412.1.1

ICZN [International Commission on Zoological Nomenclature] (1999) International Code of Zoological Nomenclature. International Trust for Zoological Nomenclature, London, 306 pp.

Mandaville JP (1990) Flora of Eastern Saudi Arabia. Kegan Paul International, London, 482 pp. [+22 maps]

Michener CD (2007) The Bees of the World [2 $2^{\text {nd }}$ Edition]. Johns Hopkins University Press, Baltimore, 953 pp. [+20 pls]

Newman E (1834) Attempted division of British insects into natural orders. Entomological Magazine 2: 379-431.

Patiny S (1999) Systématique générique et subgénérique des Melitturga Latreille - Meliturgula Friese - Flavomeliturgula Warncke (Hymenoptera, Andrenidae, Panurginae). Bulletin de la Société Entomologique de France 104(3): 241-256.

Patiny S (2001) A new Panurginae genus from Iran: Gasparinabla g. nov. described on base of a new species: Gasparinahla megapalpae sp. nov. (Hymenoptera: Apidae: Panurginae). Linzer Biologische Beiträge 33(1): 309-313.

Patiny S (2002) Nouvelles espèces de Panurginae (Hymenoptera, Apoidea, Andrenidae) du sud de l'Ouest-Paléarctique. Notes Fauniques de Gembloux 47: 41-46.

Patiny S (2004) Two new panurgine bee (Hymenoptera: Andrenidae) species from the Nearand Middle East. Zootaxa 715: 1-7. https://doi.org/10.11646/zootaxa.715.1.1

Patiny S, Michez D (2007) Biogeography of bees (Hymenoptera, Apoidea) in Sahara and the Arabian deserts. Insect Systematics and Evolution 38(1): 19-34. https://doi. org/10.1163/187631207788784012

Popov VV (1951) On species of Poecilomelitta Friese and Meliturgula Friese (Hymenoptera, Apoidea) from Arabia. Entomologicheskoe Obozrenie 31(3-4): 577-586. [in Russian]

Popov VV (1967) The bees (Hymenoptera, Apoidea) of Iran. Trudy Zoologicheskogo Instituta Akademii Nauk SSSR 43: 184-216. [in Russian]

Ramos KS, Rozen Jr JG (2014) Psaenythisca, a new genus of bees from South America (Apoidea: Andrenidae: Protandrenini) with a description of the nesting biology and immature stages of one species. American Museum Novitates 3800: 1-32. https://doi.org/10.1206/3800.1 
Roig-Alsina A, Compagnucci LA (2003) Description, phylogenetic relationships, and biology of Litocalliopsis adesmiae, a new genus and species of South American calliopsine bees (Hymenoptera, Andrenidae). Revista del Museo Argentino de Ciencias Naturales 5(1): 99-112. https://doi.org/10.22179/REVMACN.5.35

Rozen Jr JG (2003) A new tribe, genus, and species of South American panurgine bee (Andrenidae, Panurginae), oligolectic on Nolana (Nolanaceae). In: Melo GAR, Alves dos Santos I (Eds) Apoidea Neotropica: Homenagem aos 90 Anos de Jesus Santiago Moure. Editora UNESC [Universidade do Extremo Sul Catarinense], Criciúma, 93-108.

Rozen Jr JG, Ruz L (1995) South American panurgine bees (Andrenidae: Panurginae), Part II. Adults, immature stages, and biology of Neffapis longilingua, a new genus and species with an elongate glossa. American Museum Novitates 3136: 1-15.

Ruz [-Escudero] L (1986) Classification and phylogenetic relationships of the panurgine bees (Hymenoptera-Andrenidae). PhD Thesis, University of Kansas, Lawrence, 312 pp.

Ruz L (1991) Classification and phylogenetic relationships of the panurgine bees: the Calliopsini and allies (Hymenoptera: Andrenidae). University of Kansas Science Bulletin 54(7): 209-256.

Shebl MA, Alqarni AS, Engel MS (2016) First record of the bee genus Melitta from the Arabian Peninsula (Hymenoptera: Apoidea: Melittidae). Zoology in the Middle East 62(4): 352-357. https://doi.org/10.1080/09397140.2016.1250713

Warncke K (1983 [1985]) Beiträge zur Bienenfauna des Iran 19-20 Die Gattungen Panurgus Pz. und Meliturgula Fr. (Hymenoptera, Apidae). Bollettino del Museo Civico di Storia Naturale di Venezia 34: 221-235.

Walker F (1871) A List of Hymenoptera Collected by J.K. Lord, Esq. in Egypt, in the Neighbourhood of the Red Sea, and in Arabia. With Descriptions of the New Species. E.W. Janson, London, 59 pp. 